\title{
The Music Education in College Quality Education
}

\author{
Guo Yanchuang \\ Baicheng Normal University, Baicheng, 137000, China \\ 759983841@qq.com
}

Keywords: College Education, Quality Education, Music Education

\begin{abstract}
With the rapid development of society, college education should not only cultivate students' professional ability, but also optimize students' quality education. In the process of popularizing quality education in colleges and universities, music quality education is an important way and effective measure to carry out aesthetic education and an important component of quality education in colleges and universities. It plays an irreplaceable role in cultivating college students' noble moral sentiment, good aesthetic sentiment and innovative thinking ability. It is of great significance to comprehensively improve the comprehensive quality of college students. Therefore, colleges and universities should pay attention to promote the status of music education, effectively optimize the quality of music education, and constantly improve the overall quality of students.
\end{abstract}

\section{Introduction}

The aim of quality education in colleges and universities is to improve the comprehensive quality of college students and to promote the development of each student. Quality education in colleges and universities not only attaches importance to the students' mastery of knowledge and skills, but also to the development of students' potential and personality. It is a form of education that trains students' moral, intellectual, physical, aesthetic and laborious all-round development, and is the main melody of the current educational reform in colleges and universities. There are rich forms and profound contents in quality education in universities. Colleges and universities should pay attention to quality education, create a variety of teaching atmosphere, and improve the overall quality of students. Music quality education is an important part of quality education in colleges and universities. It is one of the important ways to carry out aesthetic education. It involves all aspects of quality education. In the course of carrying out the practice of quality education, colleges and universities should give full play to the function and function of music education. Through scientific music education, students' moral level, aesthetic ability, musical accomplishment, cognitive ability and so on should be improved.

\section{The Object and Subject of College Music Education}

The music education is the key content in the university education, it has the very important value. For a long time, people think that music education in colleges and universities is a professional education, which covers or faces a group of students majoring in music. But in fact, this kind of music education view is one-sided, is narrow. Scientific music education, it radiates the group is extensive and stereoscopic, all college students belong to its educational object. Through scientific music education, it can effectively enhance the aesthetic cognition of contemporary college students, especially when college students perceive the beauty and taste of music in the beautiful notes, their own aesthetic ability and taste ability, Cognitive ability can be effectively strengthened and enhanced. Therefore, in the practice of music education in colleges and universities, we should consciously enhance cognition, consciously optimize cognition, and scientifically and comprehensively clarify the key connotation and main purpose of music education. Nowadays, with the rapid development of society, the demands of college students' comprehensive accomplishment and overall quality are becoming higher and higher. As the main content of quality education, colleges and universities only through scientific music education, consciously abandon 
the traditional music education minority, or music education professional theory and other narrow tone, bring all students into the scientific category of music education. Only by constantly improving students' musical literacy, and then enhancing their comprehensive literacy, can we promote the healthy growth of students in a scientific and comprehensive way. Therefore, the main body of music education in colleges and universities is not only the students majoring in music, nor the minority students who have musical talent or hobbies, but all the college students [1]. Therefore, the purpose of music education in colleges and universities is to make every student get the study of music basic knowledge, the edification of music art, the promotion of aesthetic taste, and the formation of sound personality, so that the comprehensive quality can be improved in an all-round way.

\section{The Main Role of Music Education in College Quality Education}

As the main content of quality education in colleges and universities, music education plays a very important role. Music education is faced with a very broad group, colleges and universities should really play the role of aesthetic education in music education, moral education, intellectual education, comprehensive and scientific promotion of the overall quality of college students.

\subsection{The Role of Music Education in Aesthetic Education}

In the process of college students' growth and development, scientific aesthetic ability can guide them to discover beauty, explore beauty and recognize beauty in time, and then form scientific cognitive ability and cultivate good psychological and moral literacy. Music is the art of expressing inner emotion with musical language which constitutes image. It conveys aesthetic experience, constructs aesthetic ideal and reveals the general characteristics of aesthetic education. Music is the crystallization of people's wisdom and the exertion of creativity. In music education, scientific aesthetic education can not only improve students' musical literacy, but also result from the infiltration of music education science. That is to say, one of the aims of music education is to improve students' aesthetic ability. Therefore, in the practice of music education, colleges and universities should improve students' aesthetic ability and carry out aesthetic education scientifically. On the one hand, scientific music education can guide students to set up scientific aesthetic standards. Music is full of aesthetic elements, whether from external symbols, internal melodies, or wonderful lyrics. In the process of college students' growth and development, their cognitive ability is constantly improved, their aesthetic ability is constantly strengthened, but under the influence of external environment, college students are likely to deviate from each other in the process of cognition. Especially when college students indulge in the network and suffer the baptism of the so-called "violence aesthetics", their aesthetic standards will be seriously "shifted". Through scientific music education, under the guidance of teachers, students can not only enjoy the beauty of multi-senses, but also improve their aesthetic standards to a great extent. Therefore, music education can cultivate college students' lofty aesthetic ideal and noble aesthetic accomplishment, and mold their perfect personality. Therefore, in the practice of music education, colleges and universities should improve students' aesthetic ability and carry out aesthetic education scientifically [2]. On the one hand, scientific music education can guide students to set up scientific aesthetic standards. Music is full of aesthetic elements, whether from external symbols, internal melodies, or wonderful lyrics. In the process of college students' growth and development, their cognitive ability is constantly improved, their aesthetic ability is constantly strengthened, but under the influence of external environment, college students are likely to deviate from each other in the process of cognition. Especially when college students indulge in the network and suffer the baptism of the so-called "violence aesthetics", their aesthetic standards will be seriously "shifted". Through scientific music education, under the guidance of teachers, students can not only enjoy the beauty of multi-senses, but also improve their aesthetic standards to a great extent. Therefore, music education can cultivate college students' lofty aesthetic ideal and noble aesthetic accomplishment, and mold their perfect personality. On the other hand, scientific music education can also help college students, on the basis of full cognition and feeling of beauty, truly discover beauty, create 
beauty, and gradually transition from perception of beauty in the outside world to cognition of their own problems. Then correct one's bad habits, optimize one's moral qualities, develop one's own imagination, and step into the journey of discovering and creating beauty. Therefore, in the educational practice, music teachers should encourage students to explore and create beauty scientifically, guide them to revise their behavior habits and optimize their own character, and gradually transition from creating external beauty to sublimating inner beauty.

\subsection{The Role of Music Education in Moral Education}

College campus is a "small society", it is the "furnace" of students. Because of the proximity between university campus and society and the openness of university education, the social cognition of students and the matching of students' professional qualities are constantly improved, and at the same time, it is more or less easy for college students to get involved in the bad atmosphere. Music education is the main content of quality education [3]. Scientific music education can optimize students' moral quality and promote their healthy growth. Based on this, music teachers in colleges and universities should give full play to the function of moral education in music education, combine with the moral education accomplishment of students at present, and improve the moral education level of students in an all-round way. On the one hand, music is a reflection of real life. A musical work is not a wood without a source, but a creative reflection of real social practice. Therefore, in the music education, the teacher effectively grasps the abundant emotion in the music content, guides the student to recognize the music work charm, then causes the widespread imagination, consciously will individual emotion and the social emotion correlation. For example, some songs eulogizing the working people include the praise and praise of the creator to the working people. Music teachers can promote students' moral education cognition, guide students to respect laborers, learn from workers, consciously set up lofty ideals, and make their own contribution to the rapid development of the motherland. On the other hand, music is the product of social practice, it comes from life, but also higher than life. The abundant emotion in the musical works, especially the patriotic emotion in the musical works, is the eternal theme. Music teachers can guide students to cultivate their patriotic feelings and establish scientific ideals and beliefs by means of revolutionary songs. For example, March of the Volunteer Army, as our national anthem, contains rich patriotic feelings. Teachers can introduce these revolutionary songs into music education, and optimize the students' moral education accomplishment while coruscating the value of revolutionary songs.

\subsection{The Role of Music Education in Intellectual Education}

With the deepening of professional knowledge and the development of social experience, the intelligence of college students has been obviously improved. Music education plays an important role in the development and improvement of college students' intelligence. Teachers should pay attention to music education as a carrier, improve the intelligence level of college students in an all-round way, give full play to the role of music education in intellectual education, and comprehensively promote the scientific growth of college students. On the one hand, music education can optimize students' cognitive ability and strengthen their memory. Music itself is a kind of creative activity, students in the music learning process, with a relaxed and happy attitude to participate in the learning practice, which is to optimize their imagination and creativity, it is very important to improve their cognitive ability. Especially, music education can enlighten students' wisdom effectively. When students are in the process of cognition, there may be some misunderstanding of thinking more or less. Scientific music education can enlighten students' wisdom while optimizing students' imagination. To give a simple example, when students recite, the relatively soothing music can improve the recitation effect, which is enough to illustrate the role of music education. At the same time, music education for college students is an important means of cultivating students' image thinking, because of the non-semantic and non-visibility of music perceptual materials, music learners have greatly developed their own image thinking. On the other hand, scientific music education can optimize students' multi-sensory cognition. College students, whether in professional study or in future work practice, need to actively use all kinds of senses to 
recognize things and recognize the world. Through scientific music education, it plays a very important role in improving students' intellectual education level [4].

\section{Measures on the Function of Music Education in College Quality Education}

As the key content of college quality education, it is necessary to improve the overall quality and level of music education to give full play to the function and value of music education. Scientific music education can promote the healthy growth of students in all directions. In order to give full play to the role of music education, teachers should carry out targeted measures in teaching practice in order to promote the overall role of music education.

\subsection{Perfecting Music Education System and Optimizing Music Curriculum}

In the practice of college quality education, it is necessary to rely on a sound music education system and a sound music curriculum system to give full play to the core function of music education and to promote the comprehensive quality of college students. On the one hand, colleges and universities should actively conform to the trend of development of the times, constantly combine the actual situation of music education at the present stage, scientifically perfect the music education system, and consolidate the key position of music education from the level of decision making. In order to provide the key carrier for the scientific development of music education, colleges and universities should incorporate music education into the overall syllabus and pay attention to teaching staff, teaching materials, personnel, equipment and so on. On the other hand, colleges and universities should optimize the music curriculum system scientifically. Colleges and universities should combine their own characteristics of education, draw up the music curriculum standard in line with the new curriculum standard, and carry out music education in the way of combining compulsory courses with elective courses at the same time. For example, the basic accomplishment of music should exist as a required course, while music appreciation can exist in the form of an elective course. At the same time, colleges and universities should also pay attention to carrying out rich and colorful music practice activities, and guide students to actively optimize their aesthetic and appreciation ability in practical activities. Guide students to enrich their own musical vision and cognition from music club activities [5].

\subsection{Implementing School-based Textbook Strategy to Improve Teachers' Literacy in an All-round Way}

All along, the level of music education in colleges and universities is often low. The key to this problem lies in the lack of scientific teaching materials as the carrier, and the lack of necessary teachers in music education in colleges and universities. Therefore, to improve the overall quality of music education in colleges and universities, we should carry out the strategy of school-based teaching materials scientifically and improve the overall quality of music teachers in an all-round way. On the one hand, colleges and universities should combine their own characteristics of professional settings and music teaching characteristics, and compile their music teaching materials. Colleges and universities should set up a music teaching and research office, on the basis of general investigation and argumentation, actively absorb students' opinions or suggestions, carry out extensive and scientific decision-making, and improve the applicability and practicability of music textbook compilation. At the same time, in the selection of the content of music teaching materials, we should choose the excellent and suitable teaching materials for college students, not only the foreign textbooks with mature music education theory and successful music teaching experience. Moreover, we should select the excellent teaching materials with the characteristics of Chinese national culture, and make excellent traditional music, local music and original ecological music into the classroom together. On the other hand, colleges and universities should also focus on promoting the professional quality of music teachers. As the main guide of music education in colleges and universities, music teachers' musical literacy, their aesthetic ability and their practical experience all affect the function of music education. Based on this, colleges and universities should make great efforts to introduce high-quality music teachers and create an integrated team of music 
teachers. Colleges and universities should not only carry out scientific teacher training system, but also pay attention to the introduction of high quality talents. At the same time, colleges and universities should set up music studio scientifically, open to college students actively and improve their music practice ability.

\section{Conclusion}

In college quality education, music education is a very key content. As the main base of quality education, colleges and universities should give full play to the function of music education. After fully defining the core roles of music education, such as aesthetic, moral and intellectual education, colleges and universities should adopt the perfection of music education system, music curriculum system and the compilation of music teaching materials. The improvement of music teacher's accomplishment and so on optimizes the university student's music accomplishment and the comprehensive accomplishment.

\section{References}

[1] LU Chaoran, The Music Education in College Quality Education [J], Northern Music, 2017(10): 159-159.

[2] YANG Baiying, Study on Music Education in College quality Education [J], Home Drama, 2016(08): 12-15.

[3] JI Yanyan, Study on Music Education in College quality Education [J], Home Drama, 2015(22): 214-214.

[4] WANG Zujun, Study on Music Education in College quality Education [J], Qualitied Parents, 2015(50): 23-25.

[5] XU Xiujun, Study on the Cultivation of College Students' Creative Thinking in Music Quality Education [J], Ability and Wisdom, 2018(02):34-36. 